\title{
Epidermolysis Bullosa Simplex
}

National Cancer Institute

\section{Source}

National Cancer Institute. Epidermolysis Bullosa Simplex. NCI Thesaurus. Code C84692.

A genetic skin disorder caused by mutations in the KRT 5 and KRT 14 genes. It is characterized by the formation of blisters and increased frag ility of the skin. 